\title{
Custom-Breaker: Writing the Life of Elizabeth Cary
}

\author{
Ursula Hurley
}

\author{
I'll be the custom-breaker: and begin \\ To show my sex the way to freedom's door \\ (Elizabeth Cary, The Tragedy of Mariam, I, iv, 309- 310)
}

\begin{abstract}
On December 17, 1612, a play was licensed at the Stationer's Register. The play was titled The Tragedie of Mariam, the Faire Queene of Jewry. Set in old Testament Judea, it dramatises the plight of Herod's beautiful, chaste but outspoken wife, Mariam. In the following year this play was published in quarto form, printed by Thomas creede for the bookseller Richard Hawkins, 'to be sold,' according to the title page, 'in his shop in Chancery Lane'. ${ }^{1}$ The Tragedie of Mariam 'is the first published, original play in English known to have been written by a woman.'2 That woman was Elizabeth Cary, the Lady Falkland, and her play is of such quality that some scholars have argued for its influence on Shakespeare's othello.
\end{abstract}

Nervously, I read over my text one last time. Is it scholarly enough? Can they tell that I have no training in Early Modern manuscripts? Too late now.

I'm on my way to an awards ceremony. For the first time in my writing career, I'm attending as a shortlisted author. For the first time in my life, I'm also attending as a "biographer" - a category of learned writer which I had always believed to be beyond my capabilities. There's a pile of essays beside me, which I should be marking, but my mind is racing, vibrating along with the train. The judges wanted only one chapter and a book proposal, luring me in with their deceptively modest requirements. All those months ago when I sent my entry off, I assumed, blithely, that I would have a finished draft by now. But I haven't. I have a collection of false starts that would make a book in their own right. At this moment I have never been further away from completing a project. How can someone who has failed to tell a life story call herself a biographer?

I have to admit it. I'm stuck. This collection of gaps and fragments has become a net of words and the harder I struggle the more tightly I am snared. What is this process into

1 The title page of the 1613 edition of The Tragedy of Mariam is reproduced in the 1994 edition, edited by Barry Weller and Margaret W. Ferguson (University of California Press), 62.

2 Laurie Shannon, Sovereign Amity: Figures of Friendship in Shakespearean Contexts (University of Chicago Press, 2002), 58.

* Cary's play circulated in manuscript form for some years before its publication, so there is a good chance that Shakespeare had sight of a version of it when he was writing Othello in 1607. See, for example, Lucy Brashear, 'A Case for the Influence of Lady Cary's Tragedy of Mariam on Shakespeare's Othello', Shakespeare Newsletter 26, 1976, 31. 
which I have stumbled? This act of biography which has taken over my waking hours? The further I venture, the more I become mired in its complexity. And just when I was thinking of giving it up, an award shortlist lures me on. I look out of the window. The darkness is solid and the lights reflect my own face, questioning.

There she is. Her eyes behind mine in the dark window, looking in at this world that she couldn't possibly understand. And I'm looking back, through her eyes, into a world that I struggle to comprehend. Elizabeth Cary. My heroine, my tormentor. The woman who haunts me day and night. Which version of her is visiting me this evening? I can't quite see in the harsh glare of the lights. Is she dressed for Court, with jewels in her giant beehive hairdo? Or is she in her severe black mourning garb, eyes hollow from malnutrition? I try to explain the tea that I am drinking, electricity, trains, reassuring her that the speed of our travel won't harm her. Then I laugh at my own patronising concern. She travels through time on a regular basis, hides from me when I seek her, stalks me when I do not. Proudly, I tell her that I am a woman writer who works for her living, then worry that she will think me common or vulgar rather than liberated. She lived a long time before feminism. But she stays, gazing at me, those dark eyes unreadable as I begin to unfold the reasons for my journey, all my writerly anxieties pouring out. I'm not a biographer...

When I look up, Elizabeth has become a bride, hair bound and covered, a garland of rosemary and white roses at her brow. She taps the gold band of her betrothal ring and I know what she's telling me. 'Be and seem.' She had this motto inscribed on the inside of her daughter's wedding ring. I have never been quite sure what it means, but this evening I take it to mean that if I seem to be a biographer, that's what I shall be. Play the role and the rest will follow.

The train slows. The lights of the station dissolve my dark mirror. Elizabeth has gone, leaving the faintest hint of cloves (which she would have chewed for toothache).

The winning entry was naturally, gloriously funny, in a way that perfectly encapsulated the character of its subject. Even reading the title brought the whole room to tears of laughter (and it wasn't entirely due to the amount of champagne that had been consumed). My chapter got an honourable mention. My work was, according to the judges, 'impressively researched'. Well, that was as relief, wasn't it? I'd been anxious about being outed as an ignoramus who couldn't read Latin. But now that comment seemed almost a criticism. Research should not be so evidently impressive. That's trying too hard: 'It is the job of the biographer to interpret. But the more invisible interpretation and even judgement are, the 
better the book reads. ${ }^{3}$ The winner (and good luck to him) had found a form and a voice that allowed him access 'to felt experience where the vitality of understanding lies'. ${ }^{4}$ As we shall see, it is no coincidence that this insight is supported so helpfully by a fiction writer's craft book.

One of the judges was kind enough to seek me out and offer me encouragement. She was sure, she said, that I would 'find a way of writing it'. Confirming that I had not yet found the way. And that was what preoccupied me as I stepped into the cold night air. Staring once again at my reflection in the dark glass of the train window, Cary's words echoed. 'Be and seem.' What if she meant the writing of the biography? What if I was trying to make the text seem one thing when I was actually writing another?

I went back to my shortlisted text, seeking the answer. The first (and only) chapter becomes so engrossed in setting the scene that footnote xxxviii cites an obscure treatise on the enclosure of common grazing land in Early Modern Europe. This is biography anticipating cross-examination, caging my subject with defensive evidence. So concerned am I to uphold biographical conventions, demonstrating rigour and factual authority, that my custom-breaker has no room to breathe. Cary's writings resonate with quick intelligence, subversive wit, a dangerously sharp intellect, an integrity so heartfelt that she defied any earthly authority which threatened her freedom of conscience. My mannered approach did nothing to communicate this personality to readers, failed to gain their full, visceral attention. This was not good enough. Sorry, Elizabeth, I have dropped the torch of your custom-breaking legacy. How could I rekindle that spark and do justice to my literary heroine, the subversive innovator whose example so inspires me?

Michael Holroyd suggests that:

the literary biographer offers his subject the opportunity of writing a posthumous work in collaboration, and in the mysteries of that collaboration lie the clues to success or failure. The aim of most biographers, who live so long with their subjects, is to establish an enduring relationship and give it literary form. ${ }^{5}$

'Mysteries' and 'clues' imply a literary detective in pursuit of her subject, a thrilling chase, which relies as much on intuition and risk as it does on evidence and research. Holroyd is

3 Paula Backscheider, Reflections on Biography (Oxford: Oxford University Press, 2001), 3.

4 Janet Burroway and Elizabeth Stuckey-French, Writing Fiction: A Guide to Narrative Craft $7^{\text {th }}$ ed. (New York: Pearson Longman, 2007), 25.

5 "How I Fell into Biography" in The Troubled Face of Biography ed. Eric Homberger and John Charmley (New York: St Martin's Press, 1988), 94-103: 103. 
also careful to specify the task. A literary biographer is not, as I had assumed, seeking to write about her subject. Rather, she seeks to express the nature of her long-term relationship with the subject, and she does that via the selection and execution of an appropriate literary form.

'Form,' according to Graeme Harper, 'is historically composed, and therefore relies on a writer engaging with the nature of the world around them [...] Form, as with style, is a reflection of the writer and of the writer's world. ${ }^{6}$ The choices made by a writer can in themselves be read as an autobiographical statement. The consideration of form brings with it the autobiographical stake, which my first draft had been at pains to conceal. 'Form,' as Ronald Sukenick confirms, 'is your footprints in the sand when you look back. ${ }^{17}$ The form of my text itself would document the personal history of my relationship with Cary. And we had been wandering in this sand for a very long time.

\section{Cary and Me}

One thing, at least, was clear: the need to devise a way of writing about Cary that would perform my own stake in the process. This is a life-changing relationship (for me, at least it's more of an 'after-life' change for Cary). Questioning the absence of women on the reading list for the Early Modern paper on my English Literature undergraduate degree, my long-suffering tutor handed me a postgraduate reading list, within which I spied The Tragedy of Mariam and immediately fixated upon the play as though my life depended upon it. Why? I still have no idea. To that extent this biography is a personal quest and, perhaps for all biographers, it is only obsession that drives us on, when we would prefer to sleep, or spend time with our loved ones, or do something that pays the bills. To cut a very long story short, the strength of the personal quest element, and the need to be honest about this with my readers, eventually provided a structural answer to my formal questions. To acknowledge the personal quest dictated the production of an autobiographical frame. Once this happened, the strictures of ensnarement loosened and my text had room to breathe.

What follows, for example, is an excerpt from the autobiographical frame, which dramatises my first encounter with Cary's text. I had to order the text from America - no copy was to be had in the UK. The edition I received included a biography by one of Cary's

6 "Form and Style: Grasping the Tools of Fiction," in Wordsmithery: The Writer's Craft and Practice ed. Jayne Steele, 23-35 (Houndmills: Palgrave Macmillan, 2007), 28 - 29.

7 Ronald Sukenick, "The New Tradition in Fiction," in Surfiction: Fiction Now and Tomorrow ed. Raymond Federman (Chicago: The Swallow Press, 1975), 35. 
daughters. ${ }^{8}$ I devoured everything, transfixed:

The book was a large paperback. The covers were mainly black, apart from an extravagant filigree of sea-green swirls around the title. In the middle of these swirls was a cream rectangle which bore the following legend:

\title{
ELIZABETH CARY
}

THE LADY FALKLAND

\section{THE}

\section{TRAGEDY}

\section{OF MARIAM}

\author{
THE FAIR
}

Queen of Jewry

\author{
WITH \\ THE LADY FALKLAND \\ HER LIFE \\ BY ONE OF HER DAUGHTERS
}

\begin{abstract}
She had to be as good as Shakespeare. Better. I couldn't bear the expectation that I had heaped upon this play. Opening the cover would be like opening Pandora's Box, or the Ark of the Covenant; sparks would fly, knowledge would be unleashed, its power could sear the flesh from my bones. I sat cross-legged on my bed with the book in front of me. I picked it up and smelled the new paper. Flicked my thumb along the sharp edges of the freshly cut pages. I
\end{abstract}

8 Elizabeth Cary. The Tragedy of Mariam, The fair Queen of Jewry, With The Lady Falkland, Her Life By One Of Her Daughters. Edited by Barry Weller and Margaret W. Ferguson (Berkeley: University of California Press, 1994). 


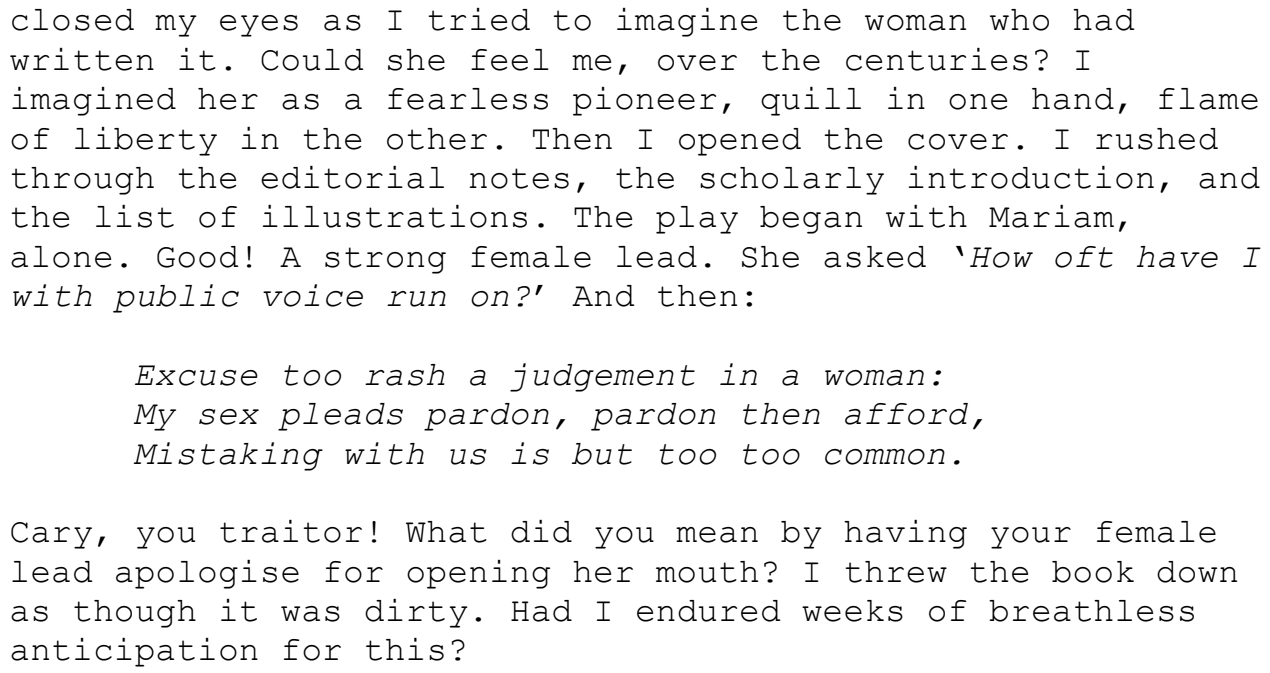

My pursuit of Cary through her writing was shaping itself as a personal narrative, as I grappled with the distortions and misunderstandings caused by our temporal distance and the limitations of my abilities as a reader and researcher. Rather than working through these issues before the writing could begin, an enabling strategy was to dramatise the difficulties and make the reader party to the process:

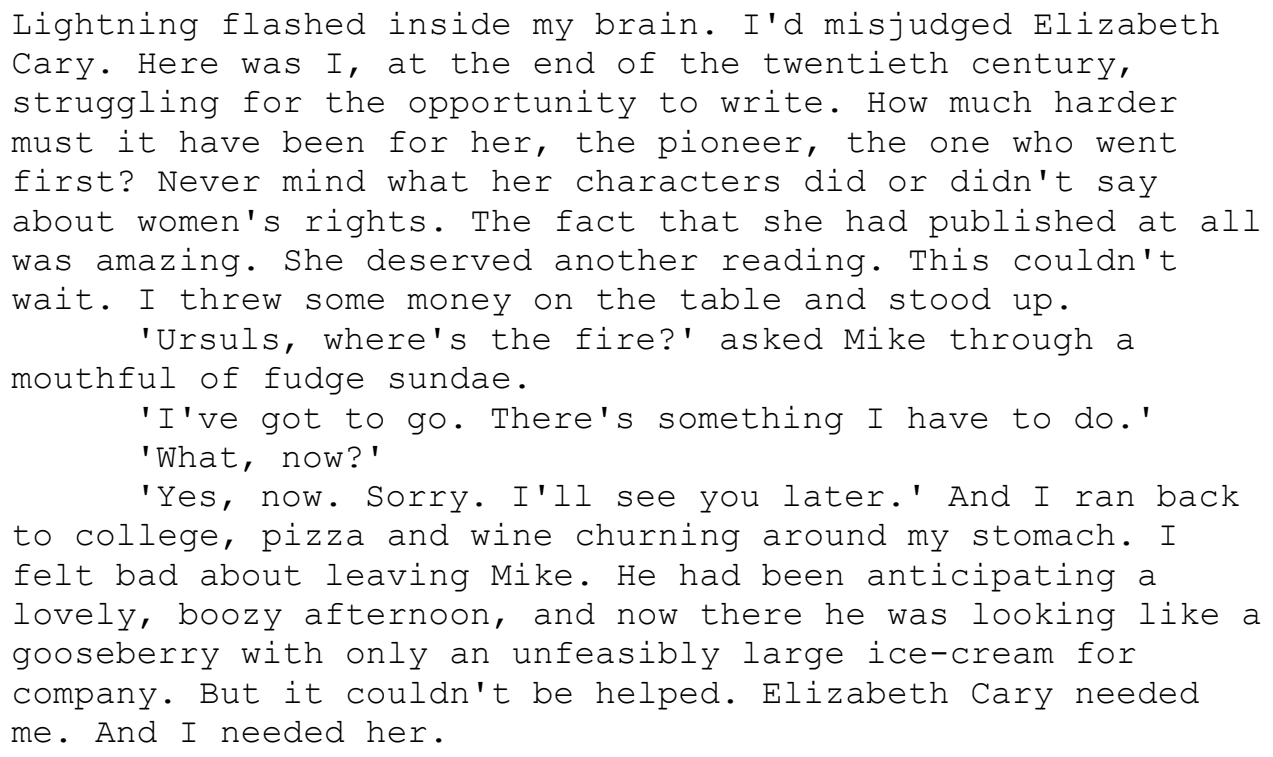

As my research revealed more of Cary's historical and social context, the more I realised not just the quality of her work, but also the sheer improbability of its being published, and having survived until I found it. My curiosity burned ever brighter. And my obsession began to shape my external reality. I turned down job offers and neglected relationships as, post-graduation, I sought ways to sustain my pursuit of her across the centuries. It is fair to say that I would not enjoy the career I have now, the place I call home and the people with 
whom I share it, had Cary not beckoned me down dark and narrow pathways.

Karolyn Schindler, reflecting upon her unanticipated role as biographer of pioneering archaeologist, Dorothea Bate, echoes a similarly opaque and instinctive experience:

It is very curious, this process of how biographers choose their subjects, and it is still a mystery to me. Perhaps it is a sort of instinctive recognition, that something in this as yet scarcely known other person - their character, profession, fate or circumstance - triggers an almost visceral response. That, at least, is what happened to me. ${ }^{9}$

Schindler encountered Dorothea at an exhibition at the Natural History Museum in London. Thousands of other people must have seen the same material and then just continued with their lives, without feeling compelled to respond by embarking upon a work of biography. Similarly, many students who complete a degree in English Literature manage to graduate and move into respectable professions, untroubled by an obsession with a long-dead playwright.

Perhaps we shall never account fully for such literary hauntings. Through chance or fate we meet someone who exists as text, in historical tracings, fall a little in love, and the biographical contract is entered into. 10

Describing these phenomena is one thing. Enacting them is something else. This is not a slick act of professional biography, but rather the result of a life's work, a quest in search of another human being who lived and breathed and loved and lost, just as we all do. I want the reader to be included in that. To share the oddness and uncanniness of my life being affected by hers. I can't experience all this and then present an objectivesounding biography that makes no mention of it. And in articulating why Cary matters to me, I attempt to make Cary matter to others, to give heart to an otherwise intellectual exercise in collating archival evidence. ${ }^{11}$

Michael Holroyd goes as far as suggesting that literary biography may one day be understood as, 'a vicarious offshoot of autobiography'. ${ }^{12}$ Such a clear acknowledgement offers an invitation to the writer. Instead of trying to pretend otherwise, a writer involved in biographical work is liberated to perform these functions explicitly, to employ autobiography (and all that the term implies about memory and subjectivity) as a strategy

9 Karolyn Schindler, Discovering Dorothea: The Life of the Pioneering Fossil Hunter Dorothea Bate. (London: HarperCollins, 2005), 1.

10 Cited by Vila-Matas in Montano, 190-191.

${ }^{11}$ The Art of the Novel: Critical Prefaces (New York: Charles Scribner's Sons, 1934), 67.

12 Holroyd, 103. 
to help us get closer to 'the vitality of understanding' which was so lacking in my earlier, unsuccessful attempts.

${ }^{13}$ Which brings us back to the old cliché that all writing is also autobiography. This does not account for texts which knowingly perform their autobiographical elements. It seems more productive, as $\mathrm{H}$. Porter Abbott suggests, to focus on 'the different orientations toward the text that they [generic classifications] elicit in the reader'. ${ }^{14}$ Thus, my overriding concern is to be honest with my reader, and to produce a text which positions them to encounter the autobiographical elements as they are intended - as a means of getting closer to Elizabeth Cary.

I am aware of the risks inherent in the decision to be openly autobiographical. There is a suspicion of vulgarity, of narcissism in an author who comes on stage, rather than sneaking around behind the scenes and pulling the strings from on high. A writer taking herself as the subject of her work, writes Jane Smiley, 'is asking for it. ${ }^{15}$ Aware of this potential to irritate my reader by my own presence, I have constructed a narrative persona in the guise of the well-meaning amateur, the inept, accidental biographer who is wittier, more self-deprecating and entertaining than I could ever be in real life. Taking permission from writers like Geoff Dyer, whose explosive text Out of Sheer Rage: In the Shadow of D.H. Lawrence 'might be a serious attempt to redefine the parameters of literary biography', I evolved 'a narrator who was me and at the same time not me'. ${ }^{16}$

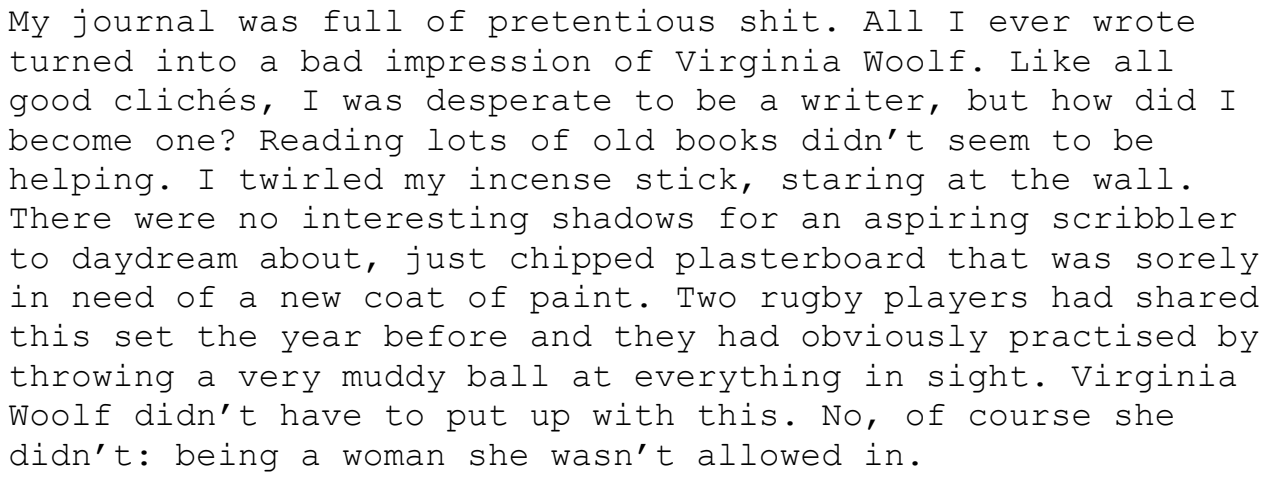

13 Paul de Man, The Rhetoric of Romanticism (New York: Columbia University Press, 1984), 921-922. Cited by H. Porter Abbott in "Autobiography, Autography, Fiction: Groundwork for a Taxonomy of Textual Categories,” New Literary History 19, No. 3 (Spring, 1988): 600-601.

14 H. Porter Abbott, "Autobiography, Autography, Fiction," 603.

15 Jane Smiley, "Lessons in Literature," The Guardian, 13 January 2007, <http://www.guardian.co.uk/books/2007/jan/13/featuresreviews.guardianreview18> accessed 07.08.2011.

16 Vivian Gornick, The Situation and the Story (New York: Farrar Straus Giroux, 2002), 22. Maggie O'Farrell, "Introduction" in Out of Sheer Rage: In the Shadow of D.H. Lawrence by Geoff Dyer (Edinburgh: Canongate, 2012), viii. 
In presenting my relationship with Cary via this narrative construct, I intend to indicate a text that is aware of its own construction, that investigates the process by which life events initiate, and in themselves become the stuff of, literary production, and that acts of literary production can initiate life events.

It was not that I couldn't think of anything else to write, and therefore, in desperation, wrote about 'myself', as Vila-Matas has his narrator claim in the auto/fictocritical text, Montano. ${ }^{17}$ Nor did I wish to treat the reader to an insight into the narrating self because, as Montano's narrator states, the reader is entitled to it. This presumes a level of interest in the reader which may not be present. They want to read the work (I hope) because it is interesting and entertaining, not because they have any great wish on a point of principle to know the narrating consciousness any better. It is rather that, in constructing a version of 'me' which inhabits the text in order to do biographical work, a mechanism is introduced to bring the reader closer to Cary. They need to see her through 'my' eyes, witness her importance to the autobiographical narrator, and the threads which still connect us; stronger than time, stronger than death. We have become symbiotic. I needed, as W.G. Sebald urges, to make clear the underpinnings, to let the reader see why the text had come about, to help them appreciate Cary's significance and influence, even from the dusty obscurity of the seventeenth century. ${ }^{18}$ In becoming part of a contemporary autobiographical text, she is less remote. She lives, in a way, through my narrative persona.

The admission of autobiography into the text had seismic effects on genre and structure, in ways that I could not have anticipated. In locating the self as a narrating consciousness, I broke open the initial idea of narrating Cary's life as a coherent and knowable account. What I had thought of as my end product - a conventional literary biography - was actually the egg from which something far more complex and vital emerged. Giving myself permission to inhabit the narrative opened myriad quicksilver possibilities, in which relativity and provisionality seemed the only possible outcomes. The autobiographical processes which so occupied my relationship with Cary are quite clearly also applicable to Cary's relationship with Mariam. Finally, I understood the 'echo chamber' in which I was working. This text had to imagine its way into and give form to Cary's text about Mariam, and to speculate on the nature of Cary's autobiographical stake in her play, The Tragedy of Mariam.

17 Enrique Vila-Matas, Montano, trans. Jonathan Dunne (London: Harvill Secker, 2007), 119.

18 W.G. Sebald's thinking is summarised in Vila-Matas, Montano, 101. 


\section{Structure - carving the Heartwood}

This project is about relationships through time and text. Of all the subjects that Cary could have chosen for her play, why Mariam? She is a shadowy presence in the Old Testament, mentioned in passing by the Jewish historian Josephus. But her story is also intriguing - a Jewish noblewoman, famed as the most beautiful of her generation, she became the second wife of Herod the Great in a political alliance that gave legitimacy to his rule while maintaining peace with Rome. Renowned as virtuous, but with an unfortunate habit of being outspoken, she clashed with Herod's female relatives and, when accusations of adultery could no longer be ignored, it seems that she chose to face execution rather than belittle herself by stooping to refute the false allegations. Public speech, female sexuality and social class are teasingly combined in this fragment of a life story, a life story which Cary chose to explore through the medium of dramatic speculation. She clearly knows her source material inside out, but at times she invents or merges characters, truncates or simplifies events, and even alters the chronology for dramatic effect. Something which would find echoes in my own work.

Part of the task of my text is to understand why Cary chose to write her play about Mariam - choosing to write, to invest time and effort and risk negative consequences must offer autobiographical insights, if only we can read 'the life of the writer as being part of a subtext of his [or her] work'. ${ }^{19}$ In telling Cary's story, I encounter Mariam's, as well as my own, and thus begins the series of interconnections that my text seeks to delineate. The Tragedy of Mariam uses accounts by the Jewish historian Josephus as the basis for its plot. $^{20}$ Josephus brings affairs of state into the domestic sphere. He tells us as much about the complexities of Herod's marriage as he does Roman foreign policy. ${ }^{21}$ This is a rich, untapped source for a dramatist and Cary handles her material with aplomb. She truncates and simplifies the plot, smooths over the gossipy contradictions, invents characters where dramatic foils are required, and mines the psychology of the situation with startling insight. We find mouthpieces for extreme points of view, from misogyny to women's rights. In Mariam, Cary has a ready-made protagonist. Beautiful, aristocratic, virtuous and outspoken. Yet passed over by the Old Testament. Cary herself does biographical work in bringing Mariam back into our awareness as a thinking, feeling person rather than a

\footnotetext{
${ }^{19}$ Holroyd, 102.

20 See Josephus, The Complete Works, trans. William Whiston (Nashville: Thomas Nelson, 1998).

21 Flavius Josephus, The Antiquities of the Jews, "How Herod Slew Sohemus and Mariamne and Afterward Alexandra and Costobarus, and his Most Intimate Friends, and at Last the Sons of Babbas Also", 1
} 
footnote in history. In giving voice to, and characterising Mariam, Cary is using the tools of the biographer to bring this life story to the reader's attention in a way that demands empathy and resonates with emotion. Now I was working with Cary, co-constructing a version of Mariam based partly upon Cary's play, and partly upon my own readings of the historical sources. Via Cary, I was now equally committed to bringing Mariam back into the light; it seems impossible to summon one without the other.

This lineage of female writers doing biographical work on female subjects extends from Mariam to Cary, and from Cary to one of her daughters in The Lady Falkland: Her Life (probably written between 1643 and 1650).' ${ }^{22}$ This latter text is often dismissed as hagiography, owing to the author's agenda, which is to celebrate and defend her mother's conversion to Catholicism. There is, however, a sharp wit at work and a vivid narrative that presences Cary in a way that later works cannot. The next biographical iteration of Cary's life continues to focus on her religious defiance and stoicism in the face of social constraints. Georgiana Fullerton published The Life of Elisabeth Lady Falkland in 1883 (London: Burns and Oates). Critics generally, and with some justification, discount this text as being too derivative of and reliant upon the Life by Cary's daughter; the biographer seeks to place in a common frame the reader and the subject, connected by shared experiences as wives and mothers with particular religious sensibilities.

The latest iteration of Cary as religious dissenter is found in Elizabeth Cary: Writer of Conscience by Ginger Roberts Brackett (Morgan Reynolds Publishing, 1996). This short text is aimed at a young adult audience in the USA. As the title suggests, Cary is cast as a religious freedom-fighter who sacrifices worldly comforts for the sake of her soul. As one reviewer notes, Brackett 'devotes a great deal of space to the theme of religious intolerance, but limits the material on Cary's contributions to society and/or literature'. ${ }^{23}$ As well as these partial biographies leaving space for my own, broader contribution, there is a sense of 'textual relay' developing here, with female biographers working from generation to generation to bring female subjects out of the dark corners and into the light. We stand on a ladder which reaches vertically through layers of history, with Mariam on the bottom rung and me standing on the uppermost rung looking down through time, via Roberts Brackett, Fullerton, Cary's daughter and Cary herself, peering through the distortions of multiple representations as my own life history becomes the focal lens for my project. Thus layers

22 Barry Weller and Margaret W. Ferguson, 'Introduction' (1-59) in The Tragedy of Mariam, The Fair Queen of Jewry by Elizabeth Cary, The Lady Falkland (Berkeley: University of California Press, 1994), 1.

23 (Pat Katka, School Library Journal, Reed Business Information Inc. 1996) 
of (auto)biographical activity accrue in ways which lend themselves to spatial and temporal metaphors as a means of representing them.

Gérard Genette's Palimpsests draws attention to the 'massive and explicit palimpsestuous' qualities of literary texts. ${ }^{24}$ Robin Nelson likens the effect to that of archaeological layering, with the traces of previous inscriptions remaining visible in the new text'. 25

This description summarises the effect I am compelled to create: to show the traces of previous lives and (auto)biographies in relation to each other, while also telling the stories of forgotten lives in ways which approach their 'vitality of understanding'.

My efforts to narrate Mariam's life amplified what Susan Tridgell describes as 'the difficulties of using a linear narrative to portray a self through time.... ${ }^{26}$ There is so little documentary evidence of Mariam's existence. This is partly due to the temporal distance, and the loss of material over the passage of years. It is also in part due to Mariam's marginalised status as a woman in the ancient world. Narrating a complete, cradle-to-grave biography would be either a frustrating list of gaps and absences, or contain so much speculation that it would have to be a fantastical fiction. In addition, there are conceptual difficulties about the realism or honesty of 'ironing out' the experience of a human life into a tidy chronolgical progression. Life is rarely experienced in this manner so how 'realistic' is it to represent lives in a linear literary form? And the final consideration, entirely practical, is the volume of words and the reader's capacity to engage with such an encyclopaedic text. To attempt complete, linear accounts of Mariam's life, Cary's life and my life would be excessive and counter-productive. It would achieve distance rather than closeness. Thus, with the archaeological inflection continuing to exert its pull, the use of fragments begins to seem not only more honest but more effective as a means of doing this biographical work.

A fragmentary or composite narrative strategy also allows the delineation of dynamic relationships between these three lives and their multiple positionings that interact as fluid, four-dimensional processes. Meanderings, repetitions and echoes lend themselves to a feminist inflection in the handling of historiography, in Julia Kristeva's terms '...recognising not the linear time of history but time as rupture and discontinuity... the

24 Gerald Prince, "Foreword" in Gérard Genette, Palimpsests: Literature in the Second Degree. Trans. Channa Newman and Claude Dubinsky (Lincoln: University of Nebraska Press, 1997), ix

25 Robin Nelson, "Set Map Slip = Palimpsest (working title) - 'working' because it is provisional and 'working' because it is on the move," Performance Research 6, no. 2 (2001): 20.

26 Understanding Our Selves: The Dangerous Art of Biography (Bern: Peter Lang, 2004), 68. 
notion of an estranging intervention in history that rearranges space. ${ }^{127}$ This seems entirely appropriate in a text whose work is to reclaim feminine experience from the margins of linear, patriarchal history, in which women's voices and women's writing are difficult to find.

In the pool of time in which we are all being pushed along by the currents of linear history, Mariam is like a rock, causing ripples which have radiated out, touching Cary, and continuing until they also touched me. We all make ripples in this pool. Usually our ripples and their effects are unseen, hidden by vastly complex patterns caused by the collisions and interactions of the ripples of others. The purpose of my text was to isolate one set of ripples and make them visible, like this:

Figure 1: Schematic representation of the text

27 Anna Smith, 'Introduction' in Julia Kristeva: Readings of Exile and Estrangement (Houndmills: Macmillan, 1996), 6. 


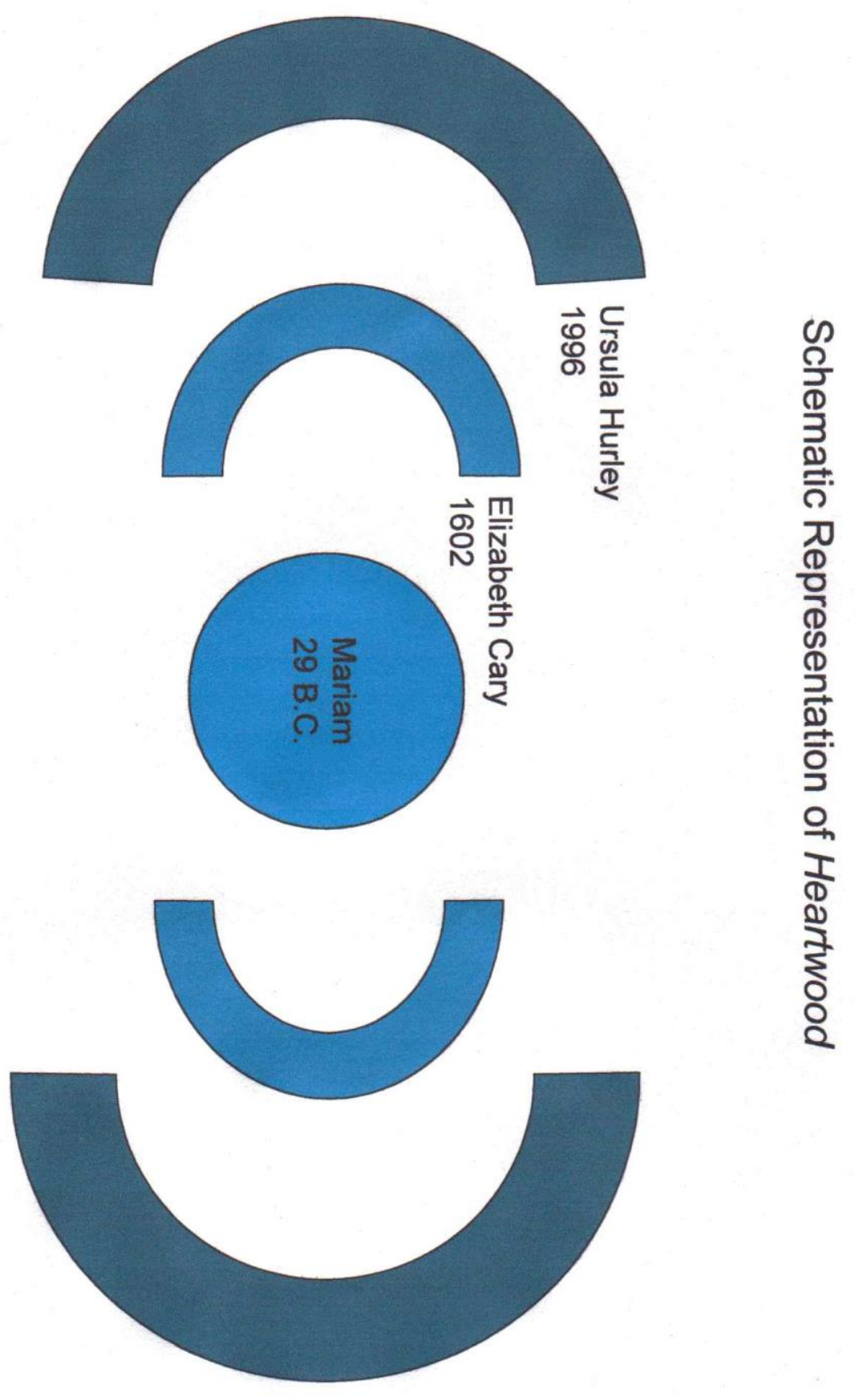


But what would I call this? And how would it work? At this point my text still lacked a name, let alone a generic classification. I showed my scribbled structure to a writer friend, who suggested that it looked like the rings of a tree. I looked up the structures of a tree trunk in my Dictionary of Biology, a battered text left over from school days. The section on trees contained a line drawing of a tree trunk in cross-section, labelled: bark, sapwood (still conducts water), annual rings, and heartwood (non-functional). ${ }^{28}$

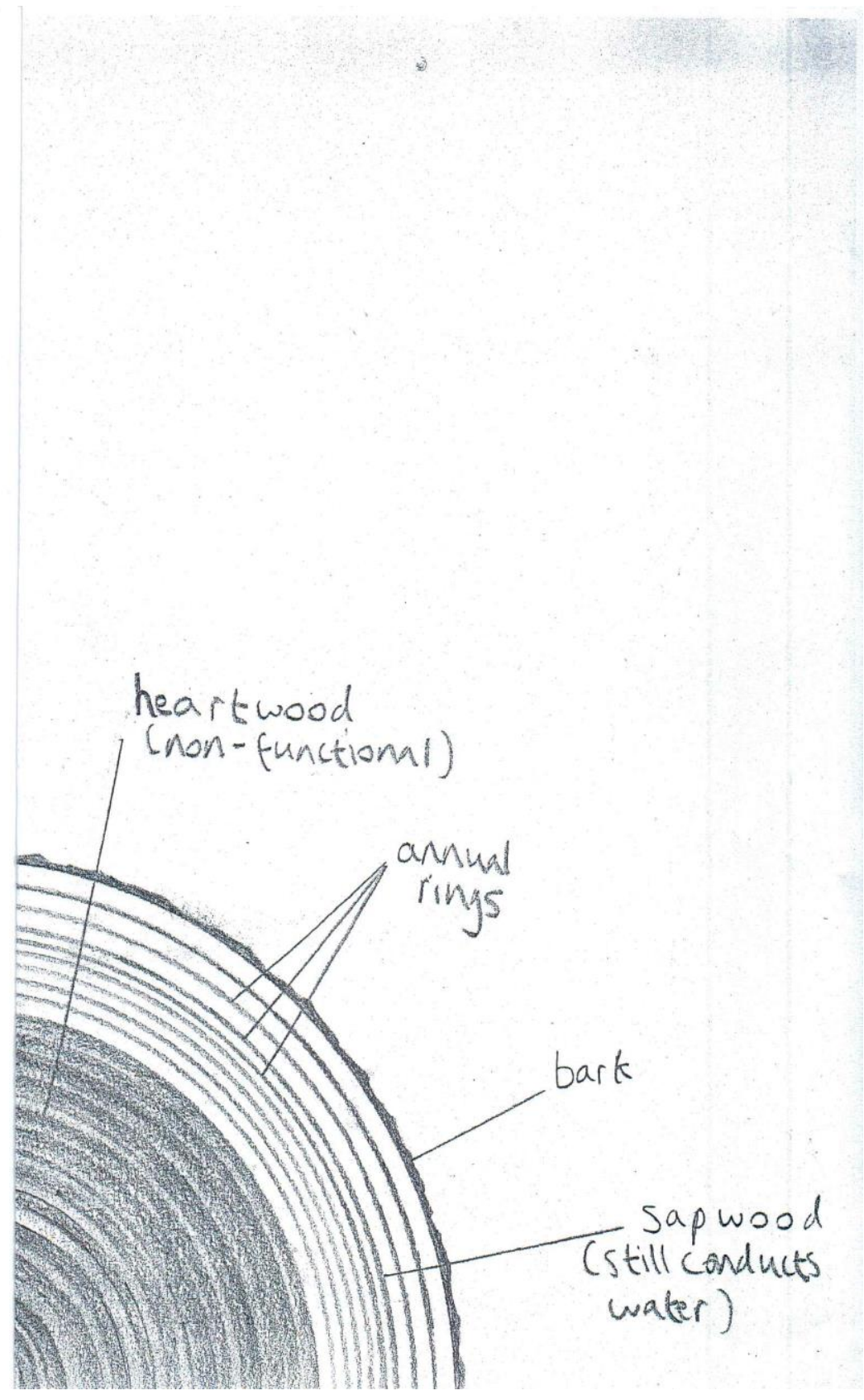

28 Neil Curtis, Longman Illustrated Dictionary of Biology: Living Organisms in all Forms Explained and Illustrated (Harlow: Longman. 1985), 172. 
'Heartwood' jumped out at me immediately. It was the evidence of the passage of time, the action of existence upon a living entity, the marks of experience. In effect, a representation of biographical processes. And I was drawn even more to the idea that it was 'non-functional'. So it no longer carried sap. Did that mean it was useless? No. Because it is a condition of the tree's existence; the tree would collapse without it. Once I made the decision to call my text Heartwood, certain resonances seemed to validate my choice. I found Fowles' The Tree while nosing through a friend's bookshelf. The title drew me immediately and I happened to open it at the page that said: 'I see trees, the wood, as the best analogue of prose fiction. ${ }^{29}$ Reading on, Fowles' comments on trees and non-linear time added to the sense that I had finally stumbled in the right direction: 'Trees warp time, or rather, create a variety of times' ${ }^{30}$ Simultaneously, a colleague who works in a very different area from my own mentioned Deleuze's thinking on the rhizome: 'the leaves of the book are like the leaves of the tree; the tree articulates and hierarchizes tracings. ${ }^{31}$ Which is precisely what I had been trying to explain with my clumsy drawings of tree trunks. Michael Holroyd's description of literary biography as 'a fantastical twig' sealed the deal. $^{32}$

\section{An aside on the use of fiction}

During these structural explorations, the need to engage historical fiction as the narrative strategy became overwhelmingly clear.

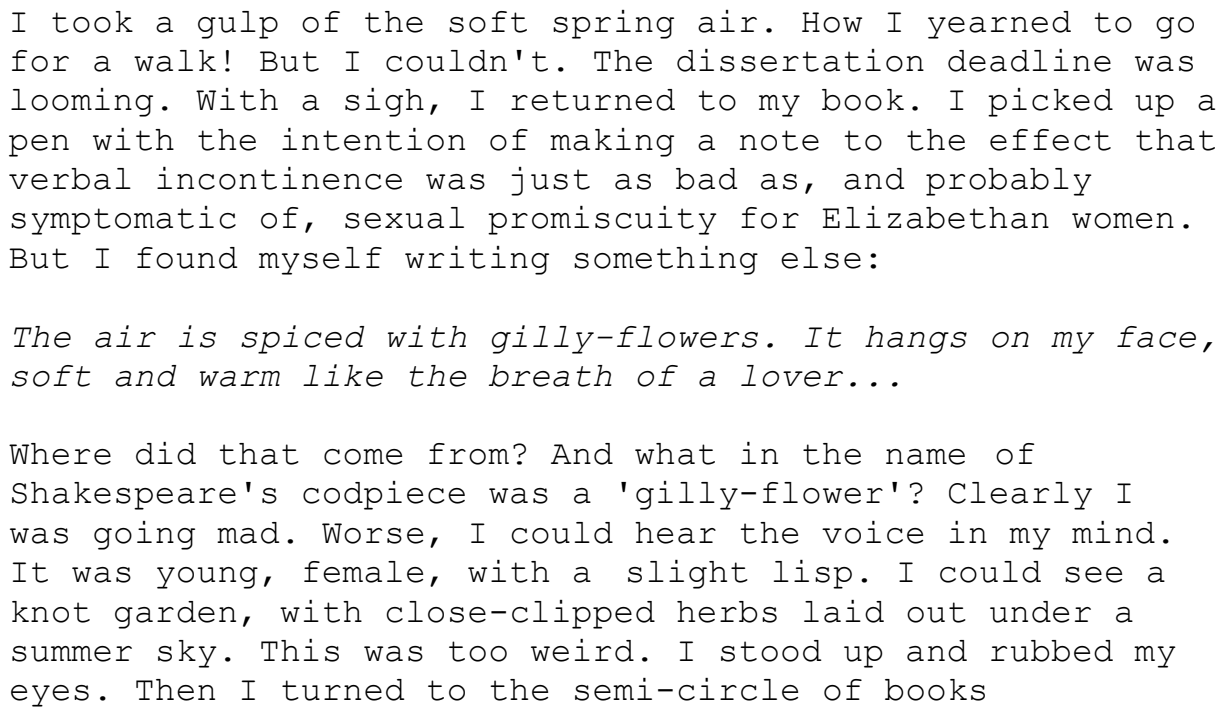

29 Ibid., 79.

30 John Fowles, The Tree (London: Vintage, 2000), 11.

31 Deleuze and Guattari, A Thousand Plateaus, 13.

32 Holyroyd, 103. 


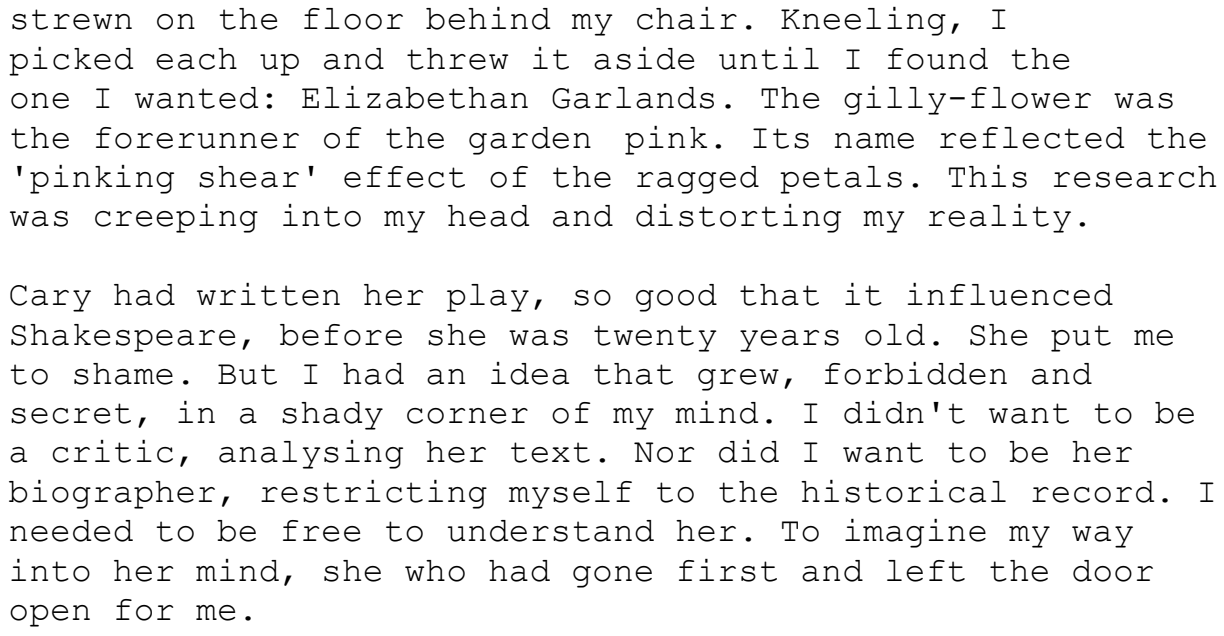

The line about gilly-flowers did pop into my head. And it did become the opening line of Cary's narrative, in third person close. It became suddenly clear that narratives of Cary and Mariam would be the novel that I admit to harbouring at the end of the autobiographical strand, which closes the whole narrative. Thus, the final line of the entire text, 'I think I'm going to write a novel', prompts the reader to reconsider the fictionalised narratives of Elizabeth and Mariam that they have already encountered as constituting the novel yet to be written.

I intend this aspect of the text to work as a historiographic meta-commentary on the processes of biography, to both narrate Cary's life, and to articulate how and why the narrative has come about. This seems particularly suited to the work of female biographers reclaiming female lives from dark corners, in which the motivations for writing and the processes of their narration form important commentaries on the often patriarchal constructions of history and the ideological agendas implicit in works of biography.

In addition to this conceptual work, engaging novelistic techniques also allow the reader to get closer to the 'vitality of experience', the quest for which began this whole adventure. Scrupulous scholarly biographies, which try to avoid such distortions, can be rather tedious, getting bogged down in what may or may not have happened and whether this source is more reliable than that. All worthy and necessary work, but serving to make such a text inaccessible to many readers. I have done the research drudgery, but kept my deliberations to myself. The reader gets the results of the hard work, without having to sit through it. It's a dramatic interpretation, based on the best information available. This attempt is cast not as a reconstruction but as a construct which aspires, through a merging of historical research and writerly craft, to approach some conception of another self's 
experience. 'To write, then, is to produce meaning, and not reproduce a pre-existing meaning. ${ }^{33}$

The role of creativity in biographical research, the act of imaginative flight across space and time, and the necessity of mediating such processes via language lead Beverley Southgate to lament 'that shadow which falls between any word and its referent, that inadequacy, inexactitude, incompleteness of which we are aware in any attempted description. ${ }^{34}$ But for the writer attempting biographical work, it is this very incompleteness that allows our work room to live, that affords the reader a role in the process of constructing an alternative reality. In this gap, the magic of imaginative empathy exists. Hence, my text's fictionalisation of Mariam and Elizabeth offers readers the opportunity to experience impressions of their subjectivities, while, via the autobiographical strand, signalling very clearly that such an opportunity is mediated through the author's (my own) concerns, interpretations, morality, philosophy, political persuasion and social and temporal position.

\section{Building the Echo Chamber}

Once I had found my title, Heartwood also provided a contribution to the content of the narratives themselves. What I needed, and what I lacked, was a turning point in each narrative, a moment of realisation when, under pressure to make a choice, the character understands something profound about the passage of time and their place in history. Suddenly the idea of using 'heartwood' literally as a plot device, and a way of demonstrating links between the narratives, became obvious. Although there were no tree stumps in any of the narratives at this stage, I found that I knew exactly where they could be worked in. Tree stumps became 'object, evidence, concept, and condition', just as Tronzo describes. ${ }^{35}$ Thus, the 'heartwood' episodes appear in the following order:

\section{Mariam}

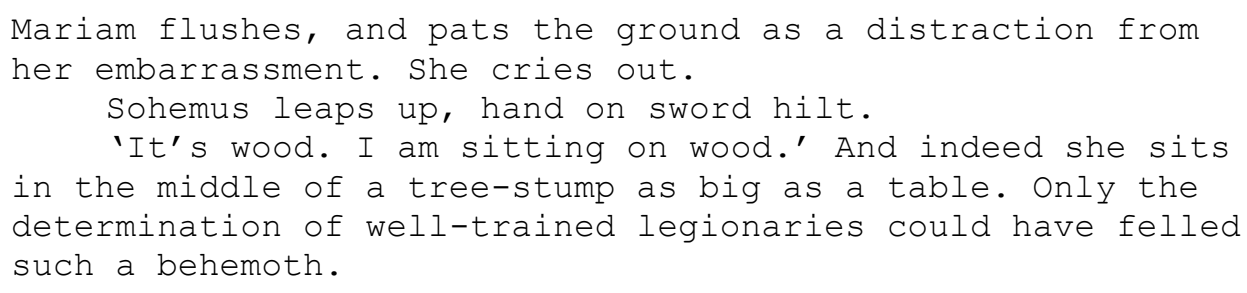

34 Beverley Southgate, History Meets Fiction (Harlow: Longman Pearson, 2009), 45.

35 The Fragment: An Incomplete History. Edited by William Tronzo (Los Angeles: Getty Publications, 2009) 
Mariam crouches and runs her hands over the stump, smoothed now by water and wind, mosses beginning to fur the surface as the rings of the heartwood are obscured. 'How old is it?'

Sohemus bends and squints. 'The rings are too many to count.'

'Was it here when my ancestor Mattathias was alive?'

'Undoubtedly. It was probably a fine tree before Jerusalem existed.'

'Think what it has seen. Oh, tree. If only you could talk.' Mariam lays her cheek against the cool moss. 'There is a mighty heart in this wood.'

'My Lady, it was cut down for a battering ram. If you wish to prevent another siege, we must go.'36

\section{Elizabeth}

She placed her hands on the ground, to brace herself as she tried to stand. 'Oh,' she gasped, as her hands slipped and she sank back to earth. She realised that she was sitting on a tree stump as big as a table. Lizzie caressed the stump, smoothed by rain and wind, furred by mosses, which obscured the rings of the heartwood. She wondered how old the tree was, what secrets it mighty heart could tell. She laid her cheek against the cool moss and wished the tree could speak. No doubt it had been felled for the Navy, consumed by the fleet that repelled the Spanish Armada. She thought that she heard its leaves sighing, flashing green in the light of a summer long passed. 'Gam zeh ya'avor,'she said to herself, remembering the Hebrew proverb about King Solomon and the ring whose engraving made sad men happy and happy men sad. 'This too shall pass,' she whispered, knowing that her whole life, no matter how difficult, would be over before a tree like this was even one tenth grown. ${ }^{37}$

\section{Ursula}

I wandered further into the darkness, until I heard the burbling of the Bin Brook, which ran along the edge of college land. I stumbled along the bank, feeling grass and twigs on my bare soles. I lifted my skirts clear so I could see my feet, pale in the shadows of the trees that lined the little stream. I stubbed my toe, and as I placed my foot again, more carefully, I was aware of a strange smoothness, as though the ground had been polished. I placed my other foot, and it made a slightly hollow noise, as though I was standing on a trap door. I hoped that I was. Wherever I dropped to would be better than this place of loneliness and betrayal.

I looked around, turning slowly like the ballerina in a musical jewellery box. As my eyes grew used to the darkness, I noticed that the ground was illuminated by a faint glow from a streetlight on the other side of the brook. I gasped as I realised that I was standing on a tree-trunk as big as a table. I knelt to caress the

36 Hurley, Heartwood, 129.

37 Ibid., 178. 


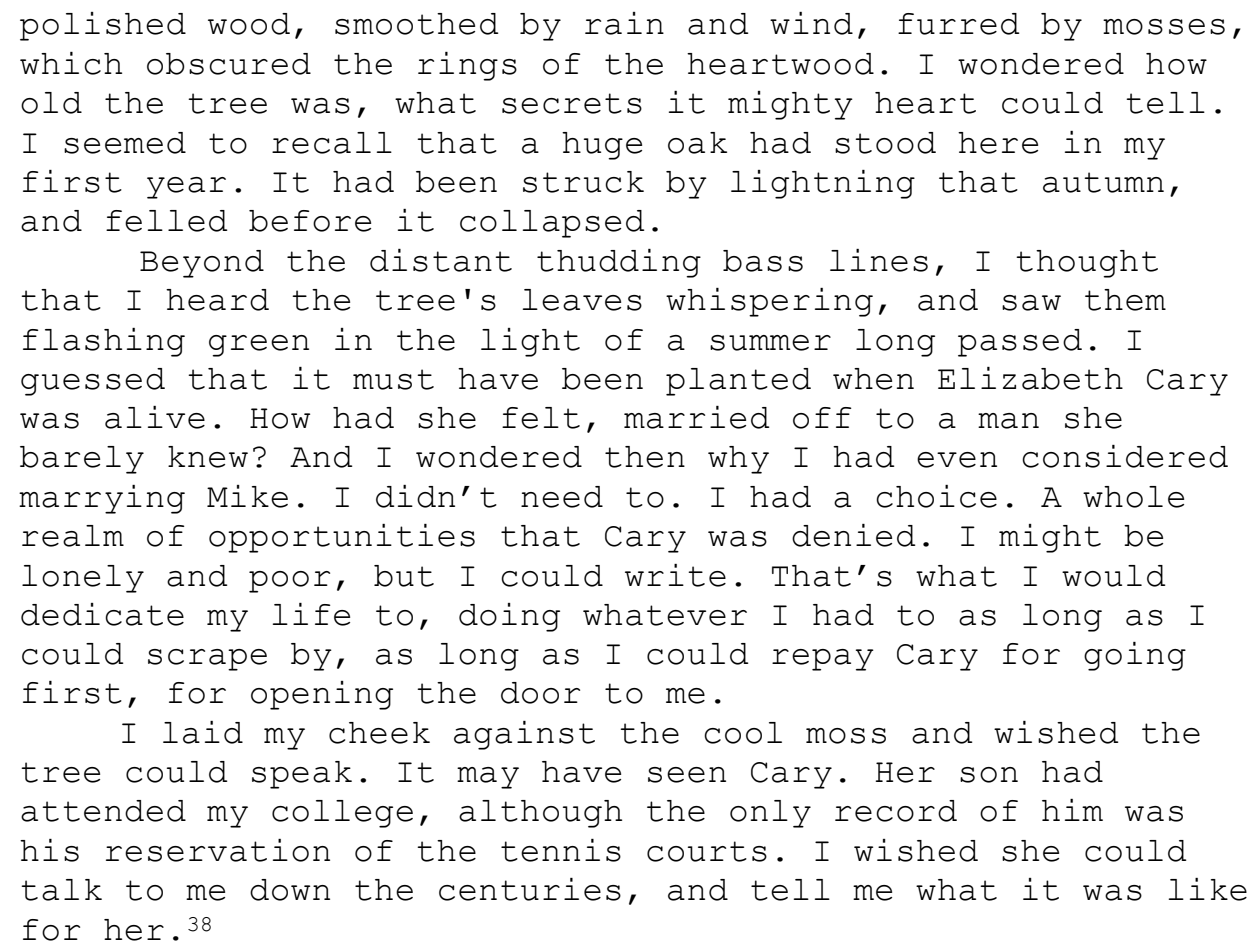

In extracting this text for comment, it becomes evident that each iteration of the heartwood motif gets longer and more elaborate, as if we were gaining a sense of perspective:

Mariam's heartwood moment is far away, viewed mainly externally. It makes sense that this is shorter because this is where the echo begins. Here, it has nothing else on which to draw, no historical context to work with. By the time we reach the Ursula narrative we have two sets of echoes to play with, and therefore there is more mileage to be had in digging down and exploiting the potential of what has been set up over the other two narrative strands. Readers may not even notice this repetition of the heartwood motif. That doesn't matter. Hopefully they will get one, and relate it to the title. But even if they don't see the allusion to structure, I hope to have planted enough links and echoes that a sense of resonance is achieved.

Heartwood's structure allows linear history to be juxtaposed with specifically feminine experiences which seem to repeat themselves in each strand of the narrative, sometimes word for word, as echoes accrue and resonate After a very long journey, and a book's worth of false starts, the idea of writing my own story of how the biographies came to be and weaving it in with the stories of Cary and Mariam, became not only clear but necessary. It was only this revelation that allowed a complete, functioning draft to emerge. And in this sense I have written not just an autobiographical frame, but a textual biography

38 Ibid., 255. 
of Heartwood itself. It is an attempt to open up other possibilities, to take the first steps towards a reading and writing practice capable of sustaining palimpsests, critiques of biographical processes, and personal quests. Whether my quest is too personal, my structure too obscure, remains to be seen. Publishers, beware. I am about to send you a proposal... 